\title{
EMPLOYEE BENEFITS IN THE CZECH REPUBLIC AND SLOVAKIA
}

\author{
[Zaměstnanecké benefity v České republice a na Slovensku] \\ Barbora Antonová ${ }^{1}, \check{Z ̌ a n e t a ~ R y l k o v a ́ ~}^{2}$ \\ ${ }^{I}$ Slezská univerzita, Obchodně podnikatelská fakulta, Univerzitní nám. 1934/3, 73340 Karviná \\ Email: antonova@opf.slu.cz \\ ${ }^{2}$ Slezská univerzita, Obchodně podnikatelská fakulta, Univerzitní nám. 1934/3, 73340 Karviná \\ E-mail: rylkova@opf.slu.cz.
}

\begin{abstract}
The paper discusses the standard, common employee benefit provided in the Czech Republic and Slovakia, analysing their popularity with employees and employers and stating which benefits were withdrawn within last years. The aim of the paper is to compare benefits that are provided in Czech Republic and Slovak Republic and at the same time confront the information gained from primary and secondary research in reference period of 2009 - 2011. In addition, the paper analyses the data obtained from primary research, which was carried out in 2012, allowing to generate a reference pool of 146 companies throughout the Czech Republic and Slovakia. Based on the primary and secondary research, the article contributes to understanding the commercial activities of businesses in terms of employee benefits.
\end{abstract}

Keywords: benefits, remuneration of employees, the Czech Republic, the Slovak Republic.

JEL classification: D22, D29, J32

Doručeno redakci: 2.4.2013; Recenzováno: 20.5.2013; 20.5.2013; Schváleno k publikování: 16.6.2014

\section{Introduction}

Employee benefits, or fringe benefits, are a remuneration component, defined as a set of rules, measures, procedures and tools to boost the interest and loyalty on part of employees towards the company they work for (ISTP, 2010). Such benefits are granted beyond the scope of the legal obligations on part of the employer.

Benefits include cash services and non-cash services provided by the employer to improve the life quality for their employee, improving thus his/her motivation, loyalty, quality and performance quantity (Profesia.sk). Benefits complement the basic remuneration, increasing its value. Essentially, this is a kind of remuneration for work differing from hourly wage and salary (Dencker, 2007). Benefits are also what a company wants to make use of to differentiate from the other market competitors and to grow attractive to potential staff members (Gossányi, 2006).

According to the Integrated System of Type Positions (2010), the principal objective for benefits should be to improve the stability and employee loyalty towards the employer. Fringe benefits should contribute to satisfying personal needs of employees, improving the attractiveness and interest in the company when recruiting skilled staff, also providing some employees with a tax relieving method of remuneration, also improving the overall performance of the company.

Such benefits are often allotted from the Fund of cultural and social needs, a social fund and profit after taxation. The provision of these perquisites is also influenced by the trade unions active in particular companies. Despite the present decline in their potential, trade unions can still intervene into what benefits are granted by the employers, on what terms and to whom. 
Considering the fact, that employee benefits increase employer's total labour cost, it's important to choose reward system properly. Mostly companies restrict providing of benefits in case that their profit or sales revenues decrease. They try to reduce spending money that are not necessary for running the company.

Certain fringe benefits, such as meal tickets and contributions to education, are legally tax deductible items for employers, while also exempt from the social and health insurances on part of the employee. The same advantage for the employee is also inherent in the contribution to the old-age pension scheme and life insurance, (Finanční noviny, 2010).

The benefit system is essentially a process based on social sensitivity. If the staff is satisfied regarding the benefits granted, they will be loyal to the employer and will not be interested in leaving the company (Dulebohn, 2009). Satisfaction at work is significantly linked to the quality of life (Krištofičová, 2006). According to a study by PayWell, nearly in all companies, employees use up their entire total financial limit for benefits (on average up to $97 \%$ ).

The aim of the paper is to compare benefits that are provided by employers in Czech Republic and Slovak Republic. This confrontation will be done on the basis of the secondary data research. And at the same time, following the results of the primary research, there will be explored relation of benefits and costs, sales and profit and also increase or decrease of benefits in period of $2009-2011$.

\section{Employee benefits in Czech and Slovak companies}

As one might expect easily, the most desirable benefit, both in the Czech Republic and Slovakia, is a financial bonus on top of the standard wage or salary. These are largely bonuses, financial rewards, financial allowances and similar (Š́uteková, 2012). The present article, however, deals mostly with non-cash benefits.

The following overview of the non-financial benefits as provided in the Czech Republic and Slovakia in 2011, listed in table 1 and table 2, as well as other data below originate from research reports by Profesia CZ, spol. s r.o., and Profesia, spol. s r.o. (Slovakia). These companies provide consultancy in labour and employment issues. They try to answer questions by subjects interested in details from the job market, and using their servers Platy.cz and Platy.sk, they are the principal providers of surveys concerning salaries, benefits, job titles and other categories in the job market. The data used here come from surveys held in 2011, involving over 109000 informants.

Table 1: Top benefits in Czech Republic in 2011

\begin{tabular}{|l|c|}
\hline \multicolumn{1}{|c|}{ Benefit } & $\begin{array}{c}\text { Share of people } \\
\text { with this benefit }\end{array}$ \\
\hline Meal tickets & $44 \%$ \\
\hline Flexible working hours & $26 \%$ \\
\hline Employee training & $18 \%$ \\
\hline Company computer also for private use & $15 \%$ \\
\hline Extra holiday & $23 \%$ \\
\hline Optional home working & $8 \%$ \\
\hline Company car also for private use & $7 \%$ \\
\hline Company weekend functions & $5 \%$ \\
\hline Contribution to health insurance & $4 \%$ \\
\hline Premium health care & $2 \%$ \\
\hline None / not used & $23 \%$ \\
\hline
\end{tabular}

Source: Platy.cz 
Tables 1 and 2 illustrate that meal tickets, so popular in the Czech Republic (offered by $44 \%$ employers), and extra holiday (provided by $23 \%$ companies) were not listed in Slovakia. So, they are not offered by employers to the same extent as in the Czech Republic. Unlike this, a nearly identical percentage of companies ( $26 \%$ in CZ, $23.5 \%$ in SK) allow their staff to work flexible hours and use a notebook computer for private use as well $(15 \%$ in CZ, $14.4 \%$ in SK). However, $20.4 \%$ Slovak companies allow staff to use their mobile phone for private use, while use of mobile phone is not listed in the Czech list at all. This might be because Czechs do not consider this a benefit any more, rather a must for performing their job duties.

Table 2: Top benefits in Slovakia in 2011

\begin{tabular}{|l|c|}
\hline \multicolumn{1}{|c|}{ Benefit } & $\begin{array}{c}\text { Share of people } \\
\text { with this benefit }\end{array}$ \\
\hline Flexible working hours & $23,5 \%$ \\
\hline Mobile phone for private use & $20,4 \%$ \\
\hline Free drinks in workplace & $20,3 \%$ \\
\hline Employee training & $18,7 \%$ \\
\hline Computer allowed for private use & $14,4 \%$ \\
\hline None / not used & $36,2 \%$ \\
\hline
\end{tabular}

Source: Platy.sk

Table 3 just below contains a summary of employee benefits in Slovakia for the first half of 2012. Minor variances are visible, due to the time variance of six months. We may note in the table that extra holiday, as mentioned above, was included this time in the table, with $9 \%$ companies granting it.

Table 3: Distribution of non-cash benefits in Slovakia (first half of 2012)

\begin{tabular}{|l|c|}
\hline \multicolumn{1}{|c|}{ Benefit } & $\begin{array}{c}\text { Share of people } \\
\text { with this benefit }\end{array}$ \\
\hline Flexible working hours & $24 \%$ \\
\hline Mobile phone for private use & $21 \%$ \\
\hline Free drinks in workplace & $19 \%$ \\
\hline Employee training & $18 \%$ \\
\hline Computer allowed for private use & $15 \%$ \\
\hline Extra contribution to food & $12 \%$ \\
\hline Contribution to old-age pension scheme & $10 \%$ \\
\hline Extra holiday & $9 \%$ \\
\hline Optional home working & $7 \%$ \\
\hline Company car also for private use & $7 \%$ \\
\hline Company weekend functions & $6 \%$ \\
\hline Reimbursement of travel costs to work & $6 \%$ \\
\hline Reimbursement of sporting and cultural events & $5 \%$ \\
\hline Premium health care & $3 \%$ \\
\hline Contribution to health insurance & $2 \%$ \\
\hline
\end{tabular}

Source: Platy.sk: Benefits are most spread

The salary survey by Platy.sk and Platy.cz indicates that in 2011, nearly two thirds (64 \%) of Slovak employees and over three quarters $(77 \%)$ of Czech employees were granted non-cash benefits. The most common benefit in Slovakia (23\%) was flexible working hours. The second most common bonus was private use of company mobile phones (20\%), used roughly by the same percentage of employees as free drinks in workplace (20\%) (Platy.sk, 2012).

By contrast, the most common benefit in the Czech Republic in 2011 were meal tickets (44\%), followed by flexible working hours (26\%), and extra holiday (26\%) ranking third (Platy.cz, 2012). 
According to Miroslav Dravecký (manager of online survey site Platy.sk), we may note that with the young generation, companies adjust the benefit structure to fit their lifestyle better. The generation of fresh graduates finds it strange to stay at work from 8 to 4 , so companies allow them to adjust work to their needs (Platy,sk, 2012).

According to the Platy.sk surveys, one out of ten Slovak employees received a contribution to his/her old-age pension scheme from the company they work for. Approximate $9 \%$ of employees are granted extra holiday above the legal minimum by their employer. The Platy.sk online salary survey indicates that most fringe benefits are granted to people within the age category of 25 to 34 years (Platy.sk, 2012).

In the Czech Republic, nearly a fifth of employees received training as a fringe benefit from the company. About 8 out of every 100 employees are granted the right to work from home. In a survey 2 years ago, Profesia $\mathrm{CZ}$ inquired among the corporate clients to find out what they base their structure of non-cash benefits on. Most often, companies make their decisions depending on the financial costs associated with a specific benefit. Despite that, companies adjust the benefit structure to the staff age to a considerable extent. The Platy.cz online salary survey indicates that most benefits are granted to people within the age category of 25 to 34 years (Platy.cz, 2012).

\section{Employee benefits and primary research}

The primary objective of the research was to examine the impact of the economic situation in period 2009 - 2011 on the provision of fringe benefits and the potential correlation between the reduced availability of these and a decrease in turnover and/or profit and increased costs on part the companies both in the Czech Republic and Slovakia. In addition, a comparison was drawn between the results for both countries. As a research method, polling was selected, more specifically, spoken interviews. The research tool consisted in a questionnaire presented to owners and top managers of particular companies.

The questionnaire survey was done in the summer term of 2012 by students of the Silesian University in Opava, the School of Business Administration in Karviná. About 700 respondents were approached; and filtering them produced 680 questionnaires duly filled and usable for the purpose of this survey. Polling took place throughout the Czech Republic and Slovakia, mainly in small and medium-sized enterprises. Respondents' selection were random. As a larger portion of the questionnaires were provided by companies operating within the Czech Republic, the final amount of questionnaires was adjusted to 146, in 1:1 parity for Czech and Slovak businesses, to suit the purpose of this paper. Narrowing the number of questionnaires from the Czech Republic was done in a manner ensuring that the final pattern matches the structure of the Slovak questionnaires. The ratio of small, medium, large-sized enterprises is 63:6:4. The criterion was the average staff size over the past three years.

The questionnaire form relied largely on closed-ended questions with an option to specify the answer in more detail. The questionnaire was split into these topic sections:

- Strategic company management

- Economic trends within company, crisis/risk management

- Company policy for human resources

- Production, services and innovative activity

- Drawing on grants and subsidies

- Energy and material savings and use of renewable resources

- Company priorities in terms of sustainable economy 
To serve the needs of the present paper, an assessment was made of the data from replies to these survey questions:

- Average staff size over past 3 years

- How did the period 2009-2011 affect company sales (turnover)?

- How did the period 2009-2011 affect company costs?

- How did the period 2009-2011 affect company profit?

- Was there a change in company benefits in 2009-2011?

The data were subsequently entered into Microsoft Office 2007 Excel application for assessment, with the results presented in the chapter below.

Based on the assumptions specified above, the following statements (S) were established.

S1: Companies noting a decline in sales have reduced the volume of fringe benefits.

S2: Companies noting an increase in costs have reduced the volume of fringe benefits.

S3: Companies noting an increase in profit have raised the volume of fringe benefits.

S4: The Czech Republic indicates a lower increase in fringe benefits compared to Slovakia.

\subsection{Survey results achieved}

The questionnaire-based survey (a selective pool of 146 informants) allowed finding out that within that total pool for Slovakia and the Czech Republic, $72 \%$ of companies did not modify their scope of employee benefits in a significant manner. Thus, the other $28 \%$ noted either an increase or decline in employee benefits. More specifically, $19 \%$ of the companies reported an increase in fringe benefits (including $14 \%$ with an increase below $30 \%$ and $5 \%$ with an increase over $30 \%$ ). As indicated in chart 1, changes in benefits are similar for both countries. In Slovakia, a larger number of companies noted an increase over $30 \%$ and decline below $30 \%$. Unlike this, the increase below $30 \%$ and decline over $30 \%$ is identical in both countries.

Unfortunately, the question failed to include a question specifying which benefits were affected by such changes most. In this context, all we can refer to are the results of the pilot round of survey done a year before. At that time, the changes proved to apply mostly to meal tickets, days of paid leave, contributions to life insurance and old-age pension schemes, contributions to holiday and education.

Figure 1: Change in benefits in Czech Republic and Slovakia

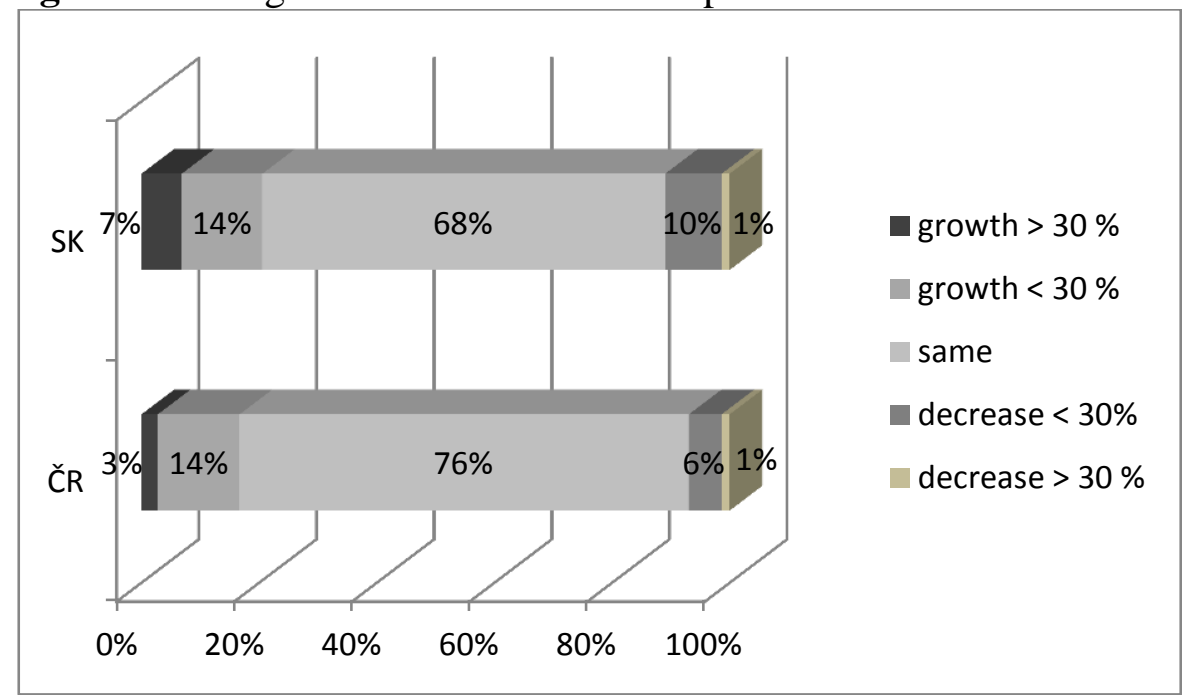

Source: own research 
The research allowed to identify which companies, in terms of their staff size, modified the fringe benefit scope most. We found that no matter what the staff size was in the company, the most common reply was that the company neither decreased nor increased the fringe benefit package in the reference period. This was particularly logical for businesses with no hired staff: if there are no employees, there is no one to offer these benefits, and as a result, there are no modifications. This was proved for Slovakia where all informants with no staff opted for "benefit stagnation" as their answer. In contrast, $17 \%$ entrepreneurs in the Czech Republic were found to have increased the fringe benefit package.

If we disregard the fact that most companies noted no change in fringe benefits, we may assume from the survery results that micro-enterprises (with staff up to 10 persons) came up with the widest range of replies. Both decline and increase were noted, and in both countries. In Slovakia, the most numerous category is the decline below $30 \%$ (for $17 \%$ of businesses). Unlike this, the most numerous category in the Czech Republic was the increase below $30 \%$, noted with $12 \%$ of businesses.

The replies were similar across the Slovak pool, for small, medium-sized and large businesses alike. If no stagnation was noted in the fringe benefit packages, there was an increase up to $30 \%$. To compare, the same increase was noted in the Czech Republic for small businesses only (staff size between 11 and 50) and medium-sized businesses (staff of 61-100). In companies with a staff of 101-250, stagnation was noted only in terms of fringe benefits, while $25 \%$ of large businesses (staff over 250) even noted a decline in the fringe benefit package below $30 \%$.

Assessments of these results allow to determine no clear correlation between the staff size and changes in fringe benefits. Yet in terms of Slovakia, one might say that the bigger the staff size is, the bigger is the increase in fringe benefits. In terms of the Czech Republic, same was true only within limits, that is, up to a staff 100 .

Because of the statements established, an analysis of the mutual correlation between selected questions is made: more specifically, we explored the correlation between the fringe benefit package and the respective sales, costs and profit.

\section{Sales}

No matter what changes were noted in sales in Slovak companies in 2009-2011, fringe benefits remained largely unchanged, and that applied to the range of $63-79 \%$ of businesses. Still, no predominance of stagnation can be noted for the Czech Republic either. Here, for increase in sales over $30 \%$, stagnation was one of the two most frequent answers, in a 50:50 ratio. The other one was the decline below $30 \%$. In addition, there is a situation where fringe benefits grow below $30 \%$ (in $60 \%$ of companies) despite a decline in sales exceeding $30 \%$. This finding may feel slightly paradoxical, as we had assumed a decline in sales will result in a decreased fringe benefit package. In contrast, we noted for both countries that despite a decrease in sales, companies increased their fringe benefit packages.

\section{Costs}

When exploring the interdependence of changes in costs and benefits, we observed that, in analogy with the previous case, any change to the cost tended to result in small changes regarding the scope of employee benefits. Most respondents indicated stagnation. The most prominent figures were noted in companies recording a decrease in costs below $30 \%$, mostly with increases in fringe benefits, and a steady cost level, where, in contrast, a decline occurred 
in fringe benefits. The most common option in terms of the Czech Republic was a decrease in fringe benefits in case of cost increases. If costs increased above $30 \%, 50 \%$ of companies even noted a decline in fringe benefits below $30 \%$.

This time, no correlation can be proved for the reference parameters in Slovakia, while a slight implication can be noted in the Czech Republic, where decreasing costs lead to increasing fringe benefits and vice versa.

\section{Profit}

Subsequently, we analysed the correlation between changes in profit and a potential change in the fringe benefit volume. Once again, we observed a situation where any kind of change in profit leads to a prevailing option of stagnation in fringe benefits across the informant pool. This was even noted as the sole option taken for Czech companies noting a profit increase below $30 \%$. Where profit declined, fringe benefits rather seemed to rise (46\% of companies noting a decline in profit below $30 \%$ ), while the fringe benefit volume declined in companies noting profit stagnation or an increase over $30 \%$.

In Slovakia, a correlation is observed between particular parameters. If there is a profit stagnation or decline, fringe benefits increase in 15- $29 \%$ of companies. On the contrary, when profit is stagnant or rises, fringe benefits decrease in up to $50 \%$ of companies.

\subsection{Evaluation of statements}

Following the results of the primary research, the statements made for the research case are evaluated just below.

Statement S1: Companies noting a decline in sales have reduced the scope of fringe benefits. This statement is rejected. Despite "stagnation" being the most common option, we proved that there is a certain correlation between the increase in sales and fringe benefits, and that is true both for the Czech Republic and Slovakia. We proved that the decline in sales was followed by an increase in fringe benefit packages. Regarding the Czech Republic, we even noted a change exceeding $50 \%$.

Statement S2: Companies noting an increase in costs have reduced the volume of fringe benefits. This statement was rejected, as this assumption was matched by trends in the Czech Republic only. In Slovakia, the status observed failed to generate a correlation between changes in costs and fringe benefit packages.

Regarding statement S3: Companies noting an increase in profit have raised the volume of fringe benefits. This statement was rejected as well. If we disregard the most common option, "stagnation in fringe benefits", we must stress that, in particular in Slovak companies, we noted a growing profit is accompanied by a decrease in employee benefits. This fact could be a result of decreasing costs of fringe benefits, which might have allowed the companies to score a better profit margin. Important to note, the phenomenon occurred in the Czech Republic as well, albeit not so visibly as in Slovakia.

Statement S4: The Czech Republic indicates a lower increase in fringe benefits compared to Slovakia. This statement has been proved. Employing the primary research findings, $17 \%$ of informants in the Czech Republic reported an increase in fringe benefit packages, while in Slovakia, same was true for $21 \%$ of companies. 


\section{Discussion}

The study "Salary \& Benefits Guide 2009-2010" published by Robert Half, containing a summary of employee benefits and the average gross remuneration volumes for professionals in finances and accounting, sales and marketing, IT and telecommunications, human resources, logistics, customer service, management support and law, showed that in 2009, fringe benefits were heavily hit by adverse economic developments. The report indicates that companies reduced employee benefits across all industries in question. They were withdrawn in some $25-40 \%$ of cases. The benefits withdrawn most often were language courses and a bonus 13th salary (Hutar, 2010). The primary research underlying in this paper showed a decrease in the supply of benefits at mere $7 \%$. Yet we must note that the primary research referred to here was done several years later, with market conditions changed since 2009.

As no similar research was found further study of the employees' benefits problematic could be beneficial. Primary research should be deeper and questionnaire should contain question only about benefit topic. Gained data will be compare with the present ones in the future.

\section{Conclusion}

We must agree with the claim made by Kortišová (2011) that today, employee benefits are a significant part of the overall value offered by the employer, turning into a sort of competition tool for recruiting new staff and maintaining the current one. If fringe benefits had had no influence on staff activities and productivity, employers would hardly have raised the offer, in some cases, at the hard time. In addition, managers are well aware that a satisfied employee can return the investment through improved performance, resulting in a better prosperity, which, in the end, will allow the employer himself to benefit from. All of this will lead to increased profits ultimately. Still, the idea fails to match the findings from the primary research, as these show that the companies achieving a higher profit margin are likely not to invest into their staff by granting fringe benefits, as their value decreased in the companies. Quite possibly though, the condition can be temporary only. As a part of the effort to save, companies probably try to reduce all costs, not quite realising the significance of fringe benefits for employees. Managers actually need to be rational regarding such saving measures,

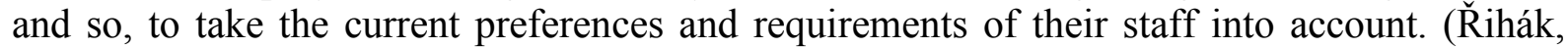
Malátek, 2012). Being careless about this option may bring about adverse impact on staff performance and the overall company prosperity.

Implementing a suitable scheme for fringe benefits is a task for every employer, who must also know some employee benefits pay off better and some other less. A fringe benefit involving little cost for the employer, yet highly appreciated by staff, is flexible working hours and the home working option. In contrast, a variety of passes to sports centres and subscription to theatre tickets may cost the employer considerably. This is mainly because these are fringe benefits that must be paid in advance to the providers, and the employer may not be able to guess how much the staff member will appreciate them really and if he/she finds any use for them at all. In such situations, it pays off to the employer to let the staff members choose which ticket or pass they would prefer or let them have another type of fringe benefit. The cafeteria system is then the easiest step to make everyone happy.

\section{Acknowledgement}

The paper was written with financial support from SGS/9/2012 project under the name "the Adaptability of business in response to the turbulent politic-economic-social and technological (PEST) environment in the context of sustainable development". 


\section{References}

[1] DENCKER, J. C., A. JOSHI and J. J. MARTOCCHIO, 2007. Employee benefits as context for intergenerational conflict. Human Resource Management Review, 17(2), 208-220. ISSN 1053-4822.

[2] DULEBOHN, J. H. a kol., 2009. Employee benefits: Literature review and emerging issues. Human Resource Management Review, 19(2), 86-103. ISSN 1053-4822.

[3] FINANČNÍ NOVINY, 2010. Daňový pohled na nejoblíbenější zaměstnanecké benefity. (Tax aspect of most popular employee benefits.) [online]. 13. srpna 2010 [vid. 25.11.2012]. Dostupné z: http://www.financninoviny.cz/zpravy/danovy-pohled-nanejoblibenejsi-zamestnanecke-benefity/515180\&id_seznam $=11550$

[4] GOSSÁNYI, V., 2006. Firmy si svoje talenty neraz rozmaznávajú. (Companies often spoil their talents) [online]. 16. listopadu 2006 [vid. 25.11.2012]. Dostupné z: http://hnonline.sk/c1-19768130-firmy-si-svoje-talenty-neraz-rozmaznavaju

[5] HUTAR, Z., 2010. Zaměstnanecké benefity za časů krize. (Employee benefits at times of crisis.) [online]. 1. dubna 2010 [vid. 28.8.2012]. Dostupné z: http://cfoworld.cz/ostatni/zamestnanecke-benefity-za-casu-krize-178

[6] INTEGROVANÝ SYSTÉM TYPOVÝCH POZICÍ (ISTP), 2010. Zamestnanecké výhody - benefity. (Employee benefits) [online]. 8. prosince 2010 [vid. 25.11.2012]. Dostupné z: http://www.istp.sk/clanky/zamestnanecke-vyhody-benefity-85.php

[7] KORTIŠOVÁ, N., 2011. Odměňování: trendem je flexibilita (Remuneration: flexibility is the trend). Moderní rízení, č. 10, 87-90, ISSN 0026-8720.

[8] KRIŠTOFIČOVÁ, D., 2006. Ked' firmy rozmaznávajú svojich zamestnancov. (When companies spoil their employees) [online]. 31. července 2006 [vid. 2.12.2012]. Dostupné z: http://profit.etrend.sk/archiv-profitu/rok-/cislo-J\%C3\%BAl/ked-firmy-rozmaznavaju-svojichzamestnancov.html

[9] PLATY.CZ, 2012. Již téměr třetina mladých lidí pracuje s pružnou pracovní dobou. (Nearly a third of young people work flexible hours) [online]. 2. března 2012 [vid. 25.11.2012]. Dostupné z: http://www.platy.cz/analyzy/jiz-temer-tretina-mladych-lidipracuje-s-pruznou-pracovni-dobou/50048

[10] PLATY.SK, 2012. Dávate správne benefity? Mladi chcú pri práci vol'nost' (Do you offer the right sort of benefits? Young people want freedom when working) [online]. 2. března 2012 [vid. 25.11.2012]. Dostupné z: http://www.platy.sk/analyzy/davatespravne-benefity-mladi-chcu-pri-praci-volnost/50047

[11] PROFESIA.SK. Benefity (Benefits) [online]. [vid. 25.11.2012]. Dostupné z: http://www.profesia.sk/cms/kariera-v-kocke/pracujem/benefity/40827

[12] ǨIHÁK, R. a V. MALÁTEK, 2012. Zaměstnanecké benefity - (ne)rutinní poskytování v kontextu sociální politiky podniku (Employee benefit: (non-) routine policy in context of corporate social policies). Acta academica karviniensia, 12(3), 120. ISSN 1212-415$\mathrm{X}$.

[13] ŠUTEKOVÁ, H., 2012. Analýza motivačných preferencií zamestnancov vo vybranom podniku. (Analysis of motivation preferences for staff in a selected company). Acta academica karviniensia, 12(3), 157. ISSN 1212-415-X. 